\title{
LEGAL INTERVENTIONS TO MEANINGFULLY INCREASE HOUSING SUPPLY IN NEW ZEALAND CITIES WITH HOUSING SHORTAGES
}

\author{
Michelle Tustin*
}

This article considers legal interventions to facilitate an affordable housing market in New Zealand. In particular, it focuses on meaningfully increasing supply and facilitating intensification and options in growing cities. It analyses the measures currently proposed by central government, including deregulation and reforms to the Resource Management Act 1991 and assesses whether these measures can achieve density and increased options and housing choices. It proposes measures such as making full use of the RMA's effects-based model, releasing National Policy Statements and carefully drafting cohesive and strategic City Plans which focus on outcomes and quality. These measures should be supported by a range of incentives, disincentives, regulations and supplementary measures to ensure the implementation of transformative town plans.

A plethora of interconnected issues have contributed to the current housing problem; economic issues like demand and social issues like immigration and NIMBY-ism (Not in my backyard). While this article focuses on meaningfully increasing supply, it acknowledges that legal interventions and supply increases are not a silver bullet solution. A smorgasbord of legal reforms as well as economic and social changes must occur to truly address affordability challenges.

\section{INTRODUCTION}

New Zealand's housing market is no longer affordable for many New Zealanders, especially first home-buyers. This is a major social, economic and political problem. Current housing supply and developments are not providing for New Zealander's needs, and the housing market is failing. One necessary measure to return to affordability is meaningful increases in supply. This involves creating and sustaining a supply of the right mix of housing choices, to meet the varying needs of New Zealand

* Submitted as part of the LLB(Hons) programme at Victoria University of Wellington. I would like to express thanks to my supervisor, Professor Richard Boast QC, for his guidance and advice during the course of this research project. 
households. Meaningful supply increases are achieved through intensification and variety in housing options; that is, multi-storey housing complexes (especially in major cities) and a range of housing sizes and styles, with particular emphasis on regaining starter homes. The regulations in current city plans are outdated, unsophisticated and not conducive to density or variety in housing options. Plans need to be fundamentally re-evaluated to ensure they are responsive and suited to modern and rapidly changing needs.

Solutions advanced by the current Government focus on unlocking unutilized greenfill land and overhauling the Resource Management Act 1991 (RMA). Deregulation which frees up land exacerbates current market failures by incentivising the exact kind of development that is producing the failures: large, single lot housing outside city limits. Supply shortages can better be attributed to lack of density, rather than lack of land. Therefore, changes to city plans should focus on transforming regulations to ensure density, not sprawl. This can be achieved through the proper implementation of the RMA's principle-based framework, removing rule-based and quantitative exclusionary regulations and replacing them with standards based on qualitative measures like quality building assessments. The RMA's framework $i$ s an effects-based model designed to allow council autonomy and implement qualitative measures, therefore it does not need to be reformed to give effect to transformative and qualitative plans which facilitate density and options. Central government can facilitate the proper implementation of the RMA through releasing National Policy Statements (NPSs) which confirm the RMA's core principles of "bottom up" decision-making and qualitative or effects-based measures. Private sector buy-in to density and options should be facilitated through a range of incentives, disincentives and regulations. Additionally, the RMA's purpose of achieving a cohesive approach to planning should be furthered through supplementary reforms.

\section{THE PROBLEM}

The Demographia International Housing Survey uses "median multiples" to calculate the affordability of housing. These are based on median house prices relative to median gross annual household incomes in cities. ${ }^{1}$ The survey defines "affordable housing" when the multiple is below 3. A multiple of above 5.1 is "severely unaffordable". ${ }^{2}$ Auckland currently has the fourth least affordable housing in the world, with a multiple of 9.7..$^{3}$ The housing problem is traversing the rest of New Zealand, where the multiple is "severely unaffordable" at 5.2. ${ }^{4}$ This impacts New Zealanders

1 Senator Bob Day 12th Annual Demographia Housing Survey (2016) (3rd quarter, 2015) at 1. This is an Australian publication which compares the affordability of housing across various comparable cities, including New Zealand cities.

2 At 2, Table ES-1.

3 At 12, Table 6. Auckland is behind Hong Kong, Sydney and Vancouver, and is tied with Melbourne and San Jose.

4 At 13, Table 7. 
immensely. It compromises New Zealand culture, which values home ownership. The property ladder enables ordinary New Zealanders to gradually increase their wealth and is a significant asset to provide New Zealanders with a degree of financial security and independence throughout their lives. Household debt has increased from 58 per cent to 147 per cent of household income between 1991 and 2011. ${ }^{5}$ This figure will rise exponentially as households assume unsustainable debt in pursuit of home ownership, threatening New Zealand's economy as the flow of money diminishes. It has significant long term socio-economic ramifications. Property ownership indicates an egalitarian society, whilst unaffordable housing could significantly contribute to wealth inequality (especially intergenerational inequality), leading to the prospect of ownership becoming heritable. ${ }^{6}$

The causes of exponential house price increases have not been definitively determined. Theories point to basic principles of supply and demand. New Zealand's population is growing; especially in cities such as Auckland and Wellington. Housing supply in these areas can no longer support their population. ${ }^{7}$

\section{A The Housing Market}

In New Zealand, house prices are determined heavily by basic market principles like supply and demand. There is strong evidence of market failures: ${ }^{8}$

(a) The current average gross annual return on investment (ROI) for Auckland landlords is three per cent. ${ }^{9}$ This minimal gross returns makes increases in rent prices imminent. With significant constituencies of renters already spending well in excess of the recommended one-third of income on housing, rent prices could rise to levels renters simply cannot afford. ${ }^{10}$ This is detrimental both to renters (who face homelessness or overcrowding) and landlords (who will be unable to find tenants). High rent also limits people's ability to save, further locking renters out of ever purchasing their own home.

5 Reserve Bank of New Zealand Statistics: Key Graphs - Household Debt <www.rbnz.govt.nz> at Figure 1.

6 See comments from David Seymour in Rob Stock "Home Ownership now for Privileged few" (12 May 2015) Stuff <www.stuff.co.nz〉.

7 Chris Parker Housing supply, choice and affordability (Auckland Council, 2015) at ii.

8 The effect of market failures is that houses and housing projects will not reflect consumer needs and will continue to be unaffordable; this will impact the ability of ordinary New Zealanders to acquire homes which provide social and economic security for families. It also creates economic problems as households take on larger debts and spend more of their income on housing, limiting their ability to purchase other goods and services which stimulate the national economy.

9 RT Greenaway-McGrevy and PCB Phillips "Hot Property in New Zealand: Empirical Evidence of Housing Bubbles in the Metropolitan Centres" (ResearchSpace@Auckland, 2015) at 11.

10 Auckland Council "The Auckland Plan: Auckland's Housing" (2012) <http://theplan.theauckland plan.govt.nz> at Figure 11.3. 
(b) Low ROI is an indicator of a housing bubble, reinforcing the need for planned measures to facilitate controlled declines in property values rather than allowing the bubble to burst. ${ }^{11}$

(c) New developments continue to focus primarily on single lot housing. House sizes have increased from 1991-2011 despite declines in household size and the ever-increasing unaffordability of large, single lot houses. ${ }^{12}$ This indicates the market is failing by not responding to consumer needs.

With median house prices so substantially above median household income, New Zealand cannot wait for the low wage economy to catch up. The only meaningful solution is to stabilize the market by reducing property values. Market failures indicate a role for legal intervention to facilitate an affordable market.

\section{SOLUTIONS}

Section 5(1) of the Resource Management Act (RMA) provides: ${ }^{13}$

The purpose of this Act is to promote the sustainable management of natural and physical resources.

This article seeks to give effect to the principles of the RMA by proposing legal interventions to facilitate long-term, sustainable increases in supply, pursuing the following goals:

(a) environmental sustainability, compliance with robust National Environmental Standards and promoting our current international obligations under the United Nations Framework Convention on Climate Change; ${ }^{14}$

(b) promoting long term market stability and keeping pace with long term growth;

(c) ensuring affordability and providing reasonable access to key city centres; and

(d) compliance with quality building assessments and relevant health and safety standards.

Increasing supply in and of itself is insufficient. Japan's free market model has historically not resulted in affordable housing, despite extensive property development. ${ }^{15}$ This is because development in Japan focused on low density housing. Only recently, when planning law was centralised to the Government who began to "force" unwanted density onto Japanese municipalities, have the extensive developments translated into high density housing which could provide

11 Greenaway-McGrevy and Phillips, above n 9, at 18.

12 Auckland Council, above n 10, at Figures 11.1 and 11.2; and Liz MacPherson National Family and Household Projections: 2013(base) -2038 (Statistics New Zealand, ISBN 978-0-908350-08-7, 29 October 2015) at 1.

13 Resource Management Act 1991, s 5(1).

14 United Nations Framework Convention on Climate Change COP 21 (opened for signature 22 April 2016, entered into force 4 November 2016).

15 See Steven Smith "Tokyo's surprising lack of density" (28 June 2012) Market Urbanism <http://marketurbanism.com>; and Wendell Cox "The Evolving Urban Form: Tokyo" (20 June 2012) New Geography <www.newgeography.com>. 
affordability. ${ }^{16}$ Whilst development was previously booming, it did not appear to be catering to the needs of its population, therefore housing remained unaffordable. Housing supply needs to be increased meaningfully through the twin pillars of intensification and options.

\section{A Intensification}

Facilitating high density housing in areas with supply problems is the natural choice in achieving sustainable supply. Redeveloped, intensified housing provides scope to keep up with growth within existing city limits. This achieves positive outcomes and meets New Zealanders' needs in various ways:

(a) It mitigates adverse impacts of urban sprawl and facilitates efficient use of existing infrastructure. ${ }^{17}$

(b) Inflated prices in "desirable" suburbs like Ponsonby and Parnell in Auckland could cool because the high cost of central land is shared across households.

(c) It ensures people's ability to effectively live and work in cities by making key city centres easily accessible from everybody's homes. Access is a vital component in affordability and successful cities; it aids economic growth and social equality whereby lower income households are not priced out of reasonable access to cities. This mitigates the emergence of "rich" and "poor" neighbourhoods and reduces the inflated value placed on central land due to its convenience.

\section{$B$ Variety of Housing Options}

Developments will continue to be unaffordable if the development of large, single lot housing continues as the preferred option. New developments need to cater to a diverse range of households; from large and small families to students, single person households, retirees and first home buyers.

Commentary has stressed the importance of viewing home ownership as a "ladder". ${ }^{18}$ The gradual elimination of "starter homes" in New Zealand might be a contributing factor in unaffordability for first home buyers. ${ }^{19}$ More affordable starter homes designed to put households on the property ladder

16 Stephen J Smith "Tokyo Takes New York: Astounding Housing Facts" (16 May 2014) Next City $<$ https://nextcity.org $>$.

17 RJ Fuller and RH Crawford "Impact of past and future residential housing development patterns on energy demand and related emissions" (2011) 26 Journal of Housing and the Built Environment 165 at 174-177, Figures 3,7 and 8 .

18 Jonathan Woetzel and others A blueprint for addressing the global affordable housing challenge (McKinsey Global Institute, October 2014) at 6-7.

19 New Zealand Productivity Commission Housing Affordability Inquiry (Prepared for the Ministers of Finance, Environment, Housing, Building and Construction and Regulatory Reform, March 2012) at 6, Figure 0.6. 
should be developed. Whilst these starter homes will not be "dream homes" they are a necessary stepping stone for first home-buyers.

Auckland has failed to provide a variety of housing options in their developments. Developers are naturally reluctant to build low end housing on extremely expensive land. ${ }^{20}$ Commentary disproves the myth that no profits can be made in low income housing or "starter" markets. ${ }^{21}$ The feasibility of developing varied housing is facilitated through high density developments. Basic principles of economies of scale indicate developers have opportunities to make profits by selling more houses per block of land.

\section{Implementation}

It may be beneficial to ensure that a range of housing exists in each development. Economically, this provides greater opportunities for individual developers to operate successful businesses and make profits notwithstanding lower house prices. Developers can use a mix of high and low end housing to balance their profits. This is important for New Zealand's primarily small scale building sector. $^{22}$

Socially, a range of housing within complexes allows a range of individuals to interact with one another. This bridges gaps in wealth, education and quality of life. It reduces the risk of creating "slums" or forcing starter and lower income homes out of reasonable city access. Singapore has successfully implemented inclusive policies in their Housing District Board (HDB) complexes. Different racial, ethnic and social groups are mixed within housing developments to prevent social stratification and promote social cohesion. ${ }^{23}$

\section{Current Regulations}

Intensification and options are both officially endorsed by central government and councils. ${ }^{24}$ However the policies advanced by councils and government conflict with their official position and fail to facilitate both pillars in practice. High density developments are excluded from the framework

20 See Phil Twyford MP "Housing and Transport in Auckland's South East" (Botany/Pakuranaga Public Meeting, 24 November 2015); and Woetzel and others, above n 18, at 43.

21 Woetzel, above n 18 , at 4.

22 New Zealand Productivity Commission, above n 19, at 170-183.

23 See Loo Lee Sim and others "Public Housing and Ethnic Integration in Singapore" (2003) 27 Habitat International 293 at 293.

24 Auckland Council The Auckland Plan: An overview (Auckland Council, 2012) at 5; David Hermans Statement of Evidence of The Ministry to Business, Innovation and Employment before the Auckland Unitary Plan Independent Hearings Panel (Ministry of Business, Innovation and Employment, Submitter No 6319, 2016) at 1; and Wellington City Council Urban Development Strategy (Wellington City Council, 2006) at 7. 
of the Housing Accord and Special Housing Areas Act 2013 (HASHAA) ${ }^{25}$ Regulations in plans often actively exclude density through exclusionary regulations and ignore the provision of diverse housing options, relying on market incentives to drive development. This section explains the current regulations in the Auckland and Wellington Plans as examples to illustrate the effect of current plans on the goals of density and options.

The Wellington Council "encourages" developers to build to maximum height and make full use of land. ${ }^{26}$ However such encouragements are "soft"; no mechanisms exist to substantively incentivise or ensure intensified developments. The Wellington plan has minimal regulatory constraints within its central business district (CBD), save maximum height requirements to achieve a gradient from the CBD to the waterfront and into the suburbs. ${ }^{27}$

The Proposed Auckland Unitary Plan (PAUP) removes some regulatory barriers to intensification from the CBD and terrace housing and apartment (THAB) zones. The THAB zone comprises only 6.5 per cent of Auckland's profile, ${ }^{28}$ and residential housing remains limited to four to six storeys. ${ }^{29}$ Its CBD is expected to accommodate approximately 50 per cent of new development in Auckland, though the CBD comprises an even smaller percentage of their housing profile (many buildings in the CBD are commercial). ${ }^{30}$

Outside the CBDs (where most housing exists), both the Auckland and Wellington plans have regulations that frustrate high density developments, like minimum car parking, size and square metre requirements and maximum heights. ${ }^{31}$ Redevelopment of inner city suburbs in Wellington like Mount Victoria and Aro Valley are stagnated by Wellington's heritage policies: 26 pages of lots are restricted

25 See Wellington City Council "Plans, Policies and By-laws: Wellington Housing Accord - Special Housing Areas" (2016) <http://wellington.govt.nz>.

26 Correspondence with Wellington Council employee (Michelle Tustin, 27 July 2016). The Council employee is unable to provide their name or be formally referenced due to their position at the Council, however the correspondence has provided insight on the practical implementation of the Council's role in consent decisions. See also Auckland Council, above n 10, at Section D, 36-65.

27 Wellington City Council employee, above n 26.

28 Todd Niall "Auckland Council Sign Off Unitary Plan" Radio New Zealand (online ed, New Zealand, 15 August 2016)

29 Auckland Council Residential - Terrace Housing and Apartment Buildings (THAB) Proposed Auckland Unitary Plan Fact Sheet (December 2015) at 1.

30 Matt Lindenberg and Amelia Linzey Joint Statement of Reply of Matthew Armin Lindenberg and Amelia Joan Linzey (On behalf of Housing New Zealand Corporation, 839, FS 3338, 2016) at 6-7.

31 See Wellington City Council District Plan Volume 1: Objectives, Policies and Rules (27 July 2000) at ch 5 : Residential Area Rules 5.2.2 (sq m), 5.6.1.3 (parking), 5.6.2.1 (site size), 5.6.2.5-7 (height), 5.3.7.5 (visual character). 
from "inappropriate subdivision or development". ${ }^{32}$ The Auckland PAUP recently accepted recommendations to loosen blanket pre-1944 building demolition controls, which were replaced with more limited controls on "character" areas. ${ }^{33}$ This means intensified developments are heavily restricted in the majority of both cities; the small percentage of land that is less restricted might be insufficient to provide the number of houses necessary.

HASHAA shifted councils' focus to addressing supply through establishing "Special Housing Areas" (SHA), however the legislation's framework substantially blocks the prospect of intensification because residential developments must be "predominantly low-rise" (under six storeys). ${ }^{34}$

The PAUP acknowledges the importance of city access, however the Ministry of Business, Innovation and Employment (MBIE) and Housing New Zealand have raised concerns regarding spatial planning in the PAUP and the disconnect between key central areas and the areas of significant planned housing development. ${ }^{35}$ The PAUP also notes challenges in providing diverse housing options, for example noting trends of larger houses being built despite decreased household sizes. ${ }^{36}$ However no mechanisms exist to achieve these options. Drafters considered proper land use regulation could facilitate the market in providing the range of housing necessary, without the need for incentives or regulations to encourage or force developers to provide choices. ${ }^{37}$

The prescriptive and exclusionary nature of current regulations in plans excludes the prospect of density, while consents are liberally granted for developments outside municipal areas, where land is cheaper. ${ }^{38}$ The combination of these factors actively disincentivises redevelopment within existing areas. Instead, developers have incentives to build outside existing limits, where land is cheaper. The distance of these land lots to city centres means they are inherently categorized as "suburban", therefore large, single-lot developments are built on these lots. This dichotomy creates market incentives for developing large, single-lot houses on cheap land outside city limits. Their size exceeds most households' needs and restricts effective access to city centres. It frustrates efforts to encourage

32 At ch 20 and ch 21

33 Connal Townsend Submission on the Proposed Auckland Unitary Plan (Property Council New Zealand, 2014) at 22-24 and 27.

34 Wellington City Council, above n 25, at [2].

35 Hermans, above n 24, at 2.

36 Auckland City Council, above n 10, at ch 11, priority 2 .

37 Correspondence with Dr Roger Blakely, Former Chief Planning Officer, Auckland Council (Michelle Tustin, 28 July 2016).

38 Wellington Council employee, above n 26. 
high density housing and urban containment and limits options by only providing one "type" of housing.

This article submits a principal cause of the housing affordability challenges is the lack of strategic intent, sophistication and cohesiveness in city plans, which regulate based on quantitative measures. This approach is outdated and makes plans unable to respond to rapidly changing needs. Councils need to fundamentally re-evaluate their plans and the processes of forming the plans to increase supply meaningfully. The rest of this article assesses possible reforms to facilitate transformative plans which create intensification and options.

\section{DEREGULATION}

The lack of land supply is often criticised as "contrived" owing to oppressive zoning laws. ${ }^{39}$ Houston and Japan are cited as examples of how removing regulations facilitates development; for example, the construction of 110,000 new housing units commenced in Tokyo in 2012. ${ }^{40}$ Removing regulations might increase short term supply, but its long term effects can be adverse. As mentioned, supply increases will not translate to affordability in itself; supply must be increased meaningfully through density and diverse housing options. This is evident from Tokyo's experience before centralisation, discussed above. Current market trends indicate incentives remain firmly with large, single-lot housing outside existing areas. Deregulation is likely to exacerbate this trend by allowing even more development of large, single-lot housing outside existing areas. Given this trend is resulting in market failure, facilitating this result through further deregulation is undesirable. Sensible regulations like urban containment could facilitate goals of density and options which ensure affordability and access by shaping the market in that direction. Complete deregulation could frustrate efforts for long-term, sustainable solutions through density and options.

\section{A Unlocking Land}

Measures to remove zones which prescribe "city limits" and unlock greenfill land for development have long been cited as a solution to inefficient town plans. The 2012 Productivity Commission Report recommended actions based on the Houston model of deregulating zoning and divesting surplus government land to "free up land" for development. ${ }^{41}$ New Zealand's implementation of such recommendations is an illustrative example of how "freeing up land" has exacerbated current market failures and distracted from the goals to meaningfully increase supply such as intensification and options.

39 Guanyu Zheng The effect of Auckland's Metropolitan Urban Limit on Land Prices (Productivity Commission, March 2013) at 10.

40 Smith, above n 16.

41 New Zealand Productivity Commission, above n 19, at 151-170. 


\section{B Housing Accord and Special Housing Areas Act (HASHAA)}

The Government seems responsive to reforms modelled on "freeing up land". The HASHAA was passed in 2013, which rezoned certain sites, creating SHA's in regions with "significant housing supply and affordability issues". ${ }^{42}$ HASHAA is temporary legislation designed to rapidly increase short-term supply. ${ }^{43}$ It is unclear what long-term measures will replace HASHAA. If the Act is considered successful, the Government may continue implementing laws and policies based on its model.

Certain streamlining measures advanced under HASHAA could form part of a long term solution, for example front end collaboration processes and focus on urban design. ${ }^{44}$ These will be discussed in further detail below. However, this article is concerned about the type of developments HASHAA is encouraging. For example, most consents in Wellington SHA's have been for single lot developments. ${ }^{45}$ This frustrates measures to achieve intensification, continuing the current "large single lot housing outside access to city centres" trend. Freeing up land will doubtless alleviate supply strains faced by growing cities. However freeing up greenfill land as a primary mechanism is shortsighted. Land is a finite resource and the populations of New Zealand cities are projected to continue growing. Focusing on finding new land is an unsustainable exercise.

Temporary legislation is often short-sighted by nature. While quick, decisive action may have been justified in these circumstances, the nature of New Zealand's expected population growth means supply is an ongoing challenge and requires sustainable, long-term solutions. Features of HASHAA which distract from efforts to intensify developments and ignore problems with lack of housing options are not conducive to robust, long-term solutions and could force supply in the wrong direction (outwards not upwards).

\section{Exclusionary Zoning and Amenity Values}

Measures which facilitate intensification in existing residential areas might be preferable to rezoning greenfill land. These measures include replacing rule-based regulations with principle-based considerations and "bottom-lines", focusing on substance and quality. Traditional zoning has been criticised as facilitating exclusionary zoning, whereby regulations intended to preserve amenity values

42 Housing Accord and Special Housing Areas Act 2013, sch 1.

43 Section 3.

44 See Elizabeth Wells "Outside the RMA comfort zone - Learnings from implementing the Housing Accords and Special Housing Areas Act 2013" (15 April 2015) Planning.org <www.planning.org.nz> at 3-5.

45 Wellington Council employee, above n 26. 
prevent intensification. ${ }^{46}$ This causes segregated communities and household exclusion to retain low density. Examples are present in many of New Zealand's city plans. ${ }^{47}$

Criticisms of exclusionary zoning are valid. New Zealand cities are capable of building intensified developments without compromising safety or quality by following international best practice guidelines. ${ }^{48}$ This article supports measures to remove unnecessary density maximums, advocating emerging models of QIMBY-ism (quality in my back yard), acknowledging that poor quality housing need not be a natural consequence of intensification. ${ }^{49}$

These recommendations are not deregulation per-se. They fundamentally re-evaluate how regulations are designed and measured. Instead of prescriptive, rule-based regulations, measures should be outcome and effects-based. Rules are both under and over-inclusive, whilst principles could look to substance and determine whether houses are fit for purpose. Instead of prescribing "one size fits all" approaches through hard rules, developers and planners should determine how best to fulfil households' needs within a framework (including minimum health and safety standards and compliance with quality building assessments). This makes plans more sophisticated and responsive. It increases the likelihood of achieving density and options by removing barriers to density and better providing for the very subjective nature of housing preferences. Regulations which measure fitness for purpose would facilitate the development of "starter housing" by permitting developments which (while still subject to quality standards) are designed primarily as "stepping stones" rather than "dream homes".

An Independent Hearings Panel (IHP) for the PAUP recommended removing prescriptive standards which cross over with the Building Act 2004, focusing on outcomes and quality building assessments..$^{50}$ The Council substantively accepted these recommendations, only retaining the minimum dwelling size standard. ${ }^{51}$ This is a positive step in facilitating quality homes that meet household needs without prescribing arbitrary rules to appease existing land owners.

46 See William Fischel "An Economic History of Zoning and a Cure for its Exclusionary Effects" (2004) 41 Urban Studies 317.

47 See Wellington City Council, above n 31.

48 See Luc Aldon and others International Guidelines on Urban and Territorial Planning (Prepared for the United Nations Human Settlements Program, 2015).

49 See Auckland Design Manual "Not in My Back Yard!" (Prepared for the Auckland Council, 2016) $<w w w . a u c k l a n d d e s i g n m a n u a l . c o . n z>$ at 5 .

50 Auckland Unitary Plan Independent Hearings Panel Report to Auckland Council Hearing Topics 059-063: Residential Zones (Prepared for the Auckland Council, 2016) at 8.

51 Auckland Council Decisions of the Auckland Council on recommendations by the Auckland Unitary Plan Independent Hearings Panel on Submissions and Further Submissions to the Proposed Auckland Unitary Plan (Auckland Council, 2016) at 48-52. 


\section{Curitiba}

The city of Curitiba in Brazil is an example of excellent strategic planning. Many ideas from its 1965 plan could be evaluated and implemented in formulating sophisticated city plans in New Zealand. Curitiba's plan facilitated efficient city development, focusing on effective transport and infrastructure. ${ }^{52}$ The plan involved radial and axial corridors of growth and intensified housing along key transport lines, clever uses of greenspace and public parks around waterways and intensified developments, substantial investment in efficient transport and infrastructure and a focus on pragmatic, interactive planning processes ${ }^{53}$ Efficient planning results in greater city accessibility, which aids in affordability. Radial and axial corridors of intensification could be effective in New Zealand by prescribing specific areas of high density housing. This ensures the amenity of lower density housing is unaffected by discrete and random developments, which could reduce objections. It would also ensure lower density areas are less affected by blocked light and ventilation from intensified developments, removing the need for exclusionary regulations to address those matters. Curitiba's plan is implemented at a minimal cost burden; the city's budget is approximately US $\$ 1$ billion per year, an extremely modest budget for a city of its size. ${ }^{54}$ Thus, Curitiba's model is not dependent on economic or social advantage. ${ }^{55}$ Curitiba's planning practices could be furthered by providing frameworks for land-use policies to facilitate land assembly to make larger, high density complexes feasible. ${ }^{56}$

\section{E Better Urban Planning}

The Government requested the Productivity Commission write a further report on freeing land which was released in 2015. ${ }^{57}$ The Productivity Commission also released a draft report on Better Urban Planning on 19 August 2016, with the final report due in February 2017. ${ }^{58}$ This report criticizes attempts by councils to micromanage planning and development decisions, encouraging a "restrained"

52 Jamie Lerner, Instituto de Pesquisa e Planejamento Urbano de Curitiba (IPPUC) Plano Preliminar de Urbanisrno (Curitiba Preliminary Urban Plan) (1965).

53 Jonas Rabinovitch "Innovative land use and public transport policy: The case of Curitiba, Brazil" (1996) 13 Land Use Policy 51 at 54.

54 See World Habitat Awards "Urban Management in Curitiba - Building Full Citizenship" (1997) Building and Social Housing Foundation <www.bshf.org>.

55 Rabinovitch, above n 53, at 52.

56 See Erik Louw "Land assembly for urban transformation - The case of 's-Hertogenbosch in The Netherlands" (2008) 25 Land Use Policy 69; and Mona Qureshi and Robin King "3 Ways Land-Use Planning and Zoning Can Increase Urban Density" (18 August 2015) The City Fix <http://thecityfix.com>.

57 New Zealand Productivity Commission Using Land for Housing (Prepared for the Ministers of Finance, Housing, Local Government and Environment, September 2015).

58 New Zealand Productivity Commission Better urban planning: Draft report (Prepared for the Ministers of Finance, Local Government, Housing, Environment and Transport, August 2016). 
approach to land use regulation. ${ }^{59}$ It outlines the benefits of not limiting the choices of households, businesses and developers and considers attempts to exert too much control in planning as limiting the benefits of city life. ${ }^{60}$ The draft plan recommends allowing a wider range of activities and requiring better evidence to justify new rules. These recommendations may not be reconcilable with principle-based planning, because they appear to be attempts to remove regulations, rather than fundamentally changing the nature of the regulations. This might conflict with another finding of the report, which is that planning contributes to wellbeing and can be used to establish clear expectations and manage disputes which provides certainty. ${ }^{61}$ Principle-based regulations could serve the purpose of allowing a wider range of developments and activities by making decisions based on outcomes and effects instead of the perceived micromanaging of the current, prescriptive plans. Principle-based decision-making also preserves vital frameworks and expectations to provide the necessary certainty, quality assurance and protection of the natural environment

\section{F Conclusions}

Zoning and other land use regulations have long been criticised for adding costs and extending or stagnating developments. The RMA's effects-based zoning and specific performance standards gives New Zealand's zoning laws greater flexibility than traditional zoning models, whilst providing frameworks to ensure health, safety and environmental protection. ${ }^{62}$ Calls for deregulation and "unlocking" land are based on the premise that town plans unreasonably constrain supply. Claims of insufficient land supply within existing limits is difficult to reconcile with the small population densities of New Zealand cities compared to more affordable international cities. ${ }^{63}$ This might indicate constrained supply is not due to lack of land, but the inability of New Zealand plans to facilitate intensified housing: a fixture of many international cities. If the PAUP is implemented effectively, it enables up to 280,000 new households within existing limits. ${ }^{64}$ This and other international best practice standards illustrate that effects-based performance zoning is capable of balancing the benefits of zoning in achieving specific outcomes and facilitating intensification. Rezoning or removing city limits is unnecessary and myopic. Regulation changes should focus on

59 At 333.

60 At ch 2

61 At 331 .

62 John R Ottensmann "The Alternative of Performance Zoning" (1999-2000) Planning \& Markets <wwwpam.usc.edu> at IV; and Geoffrey Palmer Resource Legislation Amendment Bill Submission to the Local Government and Environment Committee by the New Zealand Fish and Game Council (New Zealand Fish and Game Council, March 2016) at 2.

63 Margaret McClure "Auckland Region - Population" (2015) Te Ara, The Encyclopedia of New Zealand <www.teara.govt.nz> at 5 .

64 Niall, above n 28. 
giving effect to the RMA's intended framework by imposing qualitative standards to remove barriers to intensification and promote options.

\section{RMA REFORM}

The RMA is possibly the most tampered with legislation in recent memory. Governments constantly see the RMA as inefficient and a barrier to development. Successive amendments to the Act have been advanced, pursuing differing objectives and confusing its implementation. ${ }^{65}$ Three key features of the RMA mean its existing framework provides significant scope for facilitating responsive and transformative city plans and make substantive reform unnecessary:

(a) Its principle-based model: the RMA is designed to measure effects in a qualitative manner. ${ }^{66}$ Rule-based, exclusionary regulations are found in plans, not the RMA. Therefore reforming the RMA is unnecessary to implement qualitative plans with frameworks which facilitate density and options.

(b) Its "bottom-up" approach: the RMA delegated significant authority to councils to formulate Regional Policy Statements (RPS), write their own plans and make consent decisions. ${ }^{67}$ It provides the necessary structure of plans without dictating substantive requirements. This makes changes to the RMA unnecessary to rewrite town plans to be more sophisticated and responsive.

(c) Guidance provisions: Part 5 provides for standards, policy statements and plans. ${ }^{68}$ These were inserted to complement the "bottom-up" approach of the Act by providing a vehicle for central government to contribute to planning decisions through standards and guidance. If utilised effectively, this can strike an appropriate balance between providing assistance, resources and injecting national concerns and synergy into plans whilst still working at a local level to achieve plans which best suit particular areas.

This article will outline key areas of the RMA "marked" for reform, assessing the ability of such reforms to achieve density, options and transformative plans. It argues that the best outcomes may be achieved by utilising the three key features of the Act as they were originally intended.

65 See Ministry for the Environment "List of all RMA or amendment acts" (26 November 2015) <www.mfe.govt.nz>.

66 Palmer, above n 62, at 2; Environment Foundation and The Law Foundation "Environment Guide: RMA Introduction" (8 January 2015) <www.environmentguide.org.nz>; and Resource Management Act, pt 2.

67 Correspondence with Geoffrey Palmer (Michelle Tustin, 19 July 2016); and Environment Foundation and The Law Foundation, above $\mathrm{n} 66$.

68 Resource Management Act, pt 5. 


\section{A Public Notification}

Notification and Environment Court appeals have long been scapegoated as adding costs, removing incentives and delaying developments. ${ }^{69}$ Provisions in the RMA, such as the $s$ 7(c) requirement of giving special regard to the maintenance and enhancement of amenity values are considered to unduly permit objections based on preconceived dislikes for intensification and to overpoliticise planning and consent decisions. The truth to these statements can be disputed, which will be discussed below. Removing public participation ignores the valuable contributions of the public in promoting robust decisions. Participation provides the perspective of the "end consumer" and can ensure Councils plan cities the public want to live in and developers build houses the public want to buy.

There is no data regarding whether the costs of participation lie primarily during planning or consents. Based on correspondence and discussions with Council members and planners, there is an indication that problems associated with public participation like NIMBY-ism and lobbying are most pervasive at planning stages. ${ }^{70}$ For example, controversial consent decisions in Wellington are delegated to an independent Commissioner. ${ }^{71}$ There is no evidence the Commissioner displays bias. ${ }^{72}$ In contrast, the Auckland Council faced extensive lobbying from the Auckland 40 Group after releasing the PAUP which attempted to eliminate exclusionary, rule-based regulations in mixedhousing zones. ${ }^{73}$ The lobbying threatened the full use of urban capacity and the prospect of 280,000 new houses within existing limits. ${ }^{74}$

The current Government seemingly regards notification as a major barrier to development, previously limiting its applicability through reform. ${ }^{75}$ Public notification has been removed from HASHAA's framework. ${ }^{76}$ In 2013, amendments to the RMA changed the focus of public involvement in Auckland. ${ }^{77}$ Planners facilitated extensive front end consultation in forming the plan in exchange

69 See Sheppard \& Bendall v North Shore City Council HC Auckland 1791-SW00, May 2001 at [57].

70 Wellington City Council employee, above n 26; and Dr Roger Blakeley, above n 37.

71 Wellington City Council employee, above n 26. See also the conflict of interest provisions of the Resource Management Act, s 100A.

72 Wellington City Council employee, above n 26.

73 Dr Roger Blakeley, above n 37.

74 Niall, above $\mathrm{n} 28$.

75 Resource Management (Simplifying and Streamlining) Amendment Act 2009, s 76.

76 HASHAA, s 53; and Local Government (Auckland Transitional Provisions) Act 2010, ss 155-159.

77 Ministry for the Environment Resource Management Amendments 2013 - Fact Sheet 4 (Ministry for the Environment, Wellington, 2013) at 3-4. 
for limited appeal rights. The IHP recently assessed the plan and made recommendations to the Council. ${ }^{78}$ Only Council's refusal to accept the recommendations can be appealed.

\section{$B$ Analysis}

Mixed models of elected and appointed decision-makers might balance democracy and participation with expert, robust decisions. Facilitating extensive front end participation to avoid back end appeals is an efficient and logical option. However the amendments go further because appeal rights are removed if the Council accepts the IHP's recommendations, to which the public does not contribute. ${ }^{79}$ It is difficult for the government to support claims that abolishing participation will reduce costs when there is no research on the true nature and distribution of participation related costs. Abolishing back end objections minimises incentives to meaningfully engage with the public because it removes consequences. This undermines front end participation, turning it into a mere formality. Effective front end engagement reduces back end appeals without needing to abolish it. Alternatively, minor reforms could provide that appeals must be granted with leave, similar to the Supreme Court. This would ensure meritorious objections can be heard whilst acting as a "gate-keeper" against NIMBY complaints.

Whilst planning and consent decisions are undoubtedly frustrated by appeals based on NIMBYism, the notion that notification decimates developments is overstated. Approximately three per cent of consents are notified nationally, while under one per cent are declined. ${ }^{80}$ This indicates it is unlikely New Zealand's affordability problems are caused primarily by participation. The real effect of notification might be that the threat of notification often causes developers to restructure plans or abandon developments. ${ }^{81}$ Possibly so few developments are notified during consent processes because developers deliberately formulate plans to ensure notification is not engaged. This frustrates both the purpose of notification and the developer's ability to obtain consents for intensified development on the assumption notification will occur and objections will follow.

The best outcomes may not be achieved by limiting participation. The public ultimately buy and live in developments, therefore their contributions are valuable. It does not follow that if participation mechanisms facilitate NIMBY-ism, they should be removed. Instead, the Government and councils should consider the possibility of engaging the public and using participation to achieve the opposite

78 Auckland Unitary Council Independent Hearings Panel Report to Auckland Council Overview of recommendations on the Proposed Auckland Unitary Plan (Prepared for the Auckland Council, 2016).

79 Local Government Act, s 154.

80 See Ministry for the Environment Resource Management Act: Annual Survey of Local Authorities 1999/2000 (Ministry for the Environment, Wellington, 2001); and Anthea McClelland Resource Legislation Amendment Bill - key issues and responses (Prepared by Forest \& Bird Manawatu Branch in March 2016 Newsletter) at 2.

81 Wellington City Council employee, above n 26. 
outcome: facilitating public buy-in to intensified developments. This might be achieved through a NPS, which will be discussed below.

\section{Economic Considerations}

Another reform proposed by the Government was amending Part 2 of the RMA to specifically include urban planning considerations like affordability and remove directive terms like "protect" and "maintain". 82

The definition of sustainable resource management in s 5 of the RMA includes economic and social considerations. ${ }^{83}$ Therefore reform to Part 2 is probably unnecessary to give legal effect to considerations regarding affordability, which could easily be described as an economic and social matter. Its inclusion teamed with the softening of directive terms might have instructed decisionmakers to change the weight given to economic factors over environmental matters.

The prioritisation of economic factors over environmental considerations is becoming less viable as the effects of climate change become imminent and our international obligations under the Paris Agreement grow. ${ }^{84}$ The RMA is New Zealand's primary legal mechanism to promote sustainable resource management. Changing the weight of economic matters over environmental factors frustrates the purpose of the Act. The importance of environmental considerations should not be undermined to produce short-term supply increases. It is not a viable long-term solution given the adverse effects of an unstable environment on the economy and society. Given this article's focus on sustainable solutions, it is critical of measures which could have negative long-term effects on the environment by undermining the RMA's purposes.

\section{Separation}

The RMA focuses on two key areas:

(a) sustainable management of natural resources such as setting standards for use of water and coasts, air, soil and aquaculture; and ${ }^{85}$

(b) zoning law and District Plans for developing buildings and lots. ${ }^{86}$

Critics of the RMA have suggested a divorce between natural resource management and zoning. This sentiment is alluded to in the Productivity Commission's draft report on better urban planning,

82 Resource Management Act 1991 Principles Technical Advisory Group Report of the Minister for the Environment's Resource Management Act 1991 Principles Technical Advisory Group (Prepared for the Minister of the Environment, 2012) at 48-51.

83 Resource Management Act, s 5(2).

84 It is likely all countries will be asked to increase their commitments under the Paris Agreement over time.

85 Resource Management Act, pts 3, 6A, 7, 7A and 9.

86 Parts 4, 5, 6, 10 and 11. 
which notes that different approaches may be appropriate based on natural resources versus urban planning. ${ }^{87}$ The close relationship between natural resources and zoning and the significant impact of cities on the environment make this suggestion problematic. Looking at the subjects discretely could create problems with statute dominance and implied repeal. Decision-makers would struggle to navigate determining priority, reconciling and interpreting legislation in relation to one another. This could increase litigation, resulting in lengthier and costlier developments. Given zoning laws play a pivotal role in achieving sustainable resource management outcomes, it makes sense for the two concepts to work cohesively in one statute.

\section{E Streamlining}

The RMA is criticised as focusing on process over strategic intent. ${ }^{88}$ The current Government focuses on "streamlining" the Act to make processes more efficient. ${ }^{89}$ Streamlining is a process of continuous improvement. It is valuable and obtains cross party support, however streamlining only goes so far before it becomes "fast-tracking", compromising vital environmental standards and robust decision-making. The proposed measures discussed above illustrate this concept; changes to Part 2 of the Act as well as the public notification reforms may have adverse effects in the name of "streamlining".

The RMA's structure creates a hierarchy with over-arching principles in s 5 and specific considerations in ss 6,7 and 8. These should be implemented through National Policy Statements, RPSs and District Plans. ${ }^{90}$ This hierarchal framework means all decisions and regulations are decided against s 5 principles, providing scope for strategic planning by adopting principle-based approaches. The nature of decision-making through overarching principles instead of prescriptive rules means that streamlining can be achieved without compromising environmental standards. The RMA does not need substantive reform to remove bureaucracy and facilitate responsive plans.

\section{F Front End Collaboration}

An example of effective streamlining is pre-application meetings between developers and councils to discuss planning developments in a manner that maximises the likelihood of obtaining consents. ${ }^{91}$ With front end consultation, developers are less likely to give councils substandard

87 New Zealand Productivity Commission, above n 58, at 332.

88 Wells, above $\mathrm{n} 44$, at 2 .

89 See Ministry of the Environment, above n 65.

90 Environmental Defence Society Inc v The New Zealand King Salmon Co Ltd [2014] NZSC 38, [2014] 1 NZLR 593 at [11].

91 Wellington City Council employee, above n 26. 
information which extends processes. ${ }^{92}$ Most consents can be achieved with minimal bureaucracy through processes that provide certainty and mechanisms which promote front end communication and information sharing. ${ }^{93}$ Front end consultation processes were expanded under HASHAA: for example, the Wellington Council provides free pre-application meetings and advice for SHAs. ${ }^{94}$ The Council has formulated clear expectations for SHAs and communicated and collaborated with developers at the front end. This adds value by ensuring efficient planning and development. It streamlines processes without compromising environmental standards. These processes should continue to be made accessible.

Analysis of the proposed reforms suggest the RMA can and should be a comprehensive code regarding resource management and planning. The RMA does not require substantive reform. Its three key features provide the mechanisms to facilitate efficient and strategic town plans within the framework of environmental standards, provided it is used correctly. The core legislation does not need to be weakened to achieve affordability. This article considers the heart of the issue is not with the RMA's form, but rather its implementation.

\section{G Implementation}

Drafters of the RMA acknowledge it has become difficult to administer. ${ }^{95}$ The intention was that plans could be fluid and fit for purpose through effects-based decisions, whilst central government would involve itself in implementation through a NPS. ${ }^{96}$ Central government have abdicated this role and councils have received minimal direction on implementing entirely novel legislation. This created inefficiency and inconsistency between councils, making development costly. Many councils did not change their policies or practices following the RMA's passage, inadvertently continuing to implement the Town and Country Planning Act. ${ }^{97}$ Examples of this are: ${ }^{98}$

(a) Blanket heritage protections: an impractical regulation to apply to many aspects of planning, for example basic housing. Old housing is often run-down, inefficient and unsuited to modern needs. Heritage protections should be constrained to public sites of significance.

92 Geoff Hardy "Streamlining The Resource Management Act" (11 February 2009) Madison Hardy $<$ http://madisonhardy.com>.

93 Wellington City Council employee, above n 26.

94 Wellington City Council employee, above n 26.

95 Palmer, above n 66

96 Palmer, above n 66.

97 Town and Country Planning Act 1977 (repealed).

98 See New Zealand Productivity Commission Research note: A history of town planning (June 2015) at 7. 
Japan's experience with developments since centralization have outlined the merits of demolishing old buildings and redeveloping existing areas. ${ }^{99}$

(b) Treatment of amenity values: instead of being a relevant consideration within the decisionmaking matrix and assessed against the other matters in $\mathrm{s} 7$, amenity takes priority because of its political significance and historical weight placed on amenity over sustainability.

(c) Density restrictions: the Town and Country Planning Act is based on old English legislation when density was neither necessary nor practical. ${ }^{100}$ Density restrictions, and other principles of the old Acts have permeated through the current implementation of zoning regulations when modern technology and international best practice guidelines now provides frameworks to develop safe, high quality intensified housing and render restrictive approaches unnecessary. ${ }^{101}$ Such restrictions are now unsuitable for the modern housing environment.

Implementation problems were exacerbated through constant reforms of the RMA, leaving questions regarding new policies and implementation strategies. Much uncertainty and inconsistency was remedied with Environmental Defence Society Inc v The New Zealand King Salmon Co Ltd. ${ }^{102}$ This provided detailed guidance about the RMA's structure, implementation and comments about Part 2. This certainty is threatened when governments continually reform the RMA. This article recommends governments work within the existing RMA framework instead of continually making changes.

\section{NATIONAL POLICY STATEMENTS}

Correct implementation of the RMA includes working within its hierarchal structure. With the exception of one Coastal Policy Statement, there is no requirement in the Act for the government to release NPSs. ${ }^{103}$ Historically, the lack of NPSs has broken a vital link in the RMA hierarchy. The Government has recently released more NPSs, however there remain many gaps relevant to housing problems which councils do not have guidance on. This will be discussed later in the article. Without this guidance, councils were left to form strategies and policies which are not cohesive or efficient and retain the status quo. The financial constraints of councils limit their ability to properly draft and implement transformative plans without direction. Central government should release NPSs which focus on several areas:

99 See Smith, above n 15; and Stephen Smith "Japan Shows the Way to Affordable Megacities" (22 January 2014) Next City <https://nextcity.org>.

100 New Zealand Productivity Commission, above n 98, at 2-6.

101 See Aldon and others, above $\mathrm{n} 48$

102 Environmental Defence Society Inc v The New Zealand King Salmon Co Ltd, above n 90.

103 Resource Management Act, s 57(1). 
(a) Implementing and enhancing the RMA's purposes of local government autonomy and its effects-based framework. This includes training, education and information sharing for councils on QIMBY ideals and implementing the RMA's model effectively through qualitative measures like quality building assessments.

(b) Providing mechanisms to facilitate responsive, strategic and transformational plans that promote density and options. Government could give advice to councils on achieving this, for example through recommendations which draw on Curitiba's model.

(c) Rewriting the approaches and processes of public participation.

(d) Information sharing on International Best Practice Guidelines, the feasibility of affordable housing in high density complexes and other relevant factors for councils to impart on developers and the public.

Government should collaborate with councils in forming NPSs. The NPS relating to Freshwater Management (NPS-FM) is an excellent example of central and local government collaboration to form robust policy statements which balance guidance and central government involvement whilst working locally, providing for community needs in the context of freshwater management. ${ }^{104}$ Policy statements regarding city plans should be equally collaborative. Local government would give effect to the NPSs through Regional Policy Statements, which are used to draft District Plans. They would be expected to implement robust plans and participation processes with central government guidance.

\section{A Public Involvement}

Instead of abolishing participation, NPSs could rewrite the perception and approach of councils, developers and the public in participation procedures which reflect the true nature of balancing decisions that are in the public interests with the property rights of existing landowners. This provides meaningful engagement which is useful to Councils and developers and injects democracy into decision-making processes.

It is unhelpful for developers to deliberately formulate plans to avoid notification. The public can make valuable contributions to plans and developments. Participation should be a mutually beneficial tool for public consultation and educating developers on public needs to make their developments more "sellable". Planning has become increasingly communicative, as the needs of households and cities diversify. Developers need to understand and embrace this. ${ }^{105}$ Conversely, the public need to understand involvement was never intended to give them "veto powers" in decision-making or facilitate NIMBY-ism. Clarity could be provided on the specific nature of property rights; they do not

104 See comments of Leigh Auton in Niko Kloeten "Planners Call for National Urban Land Strategy" (8 February 2015) Stuff <www.stuff.co.nz>.

105 See R Fischler "Communicative planning theory: a Foucauldian assessment" (2000) 19 Journal of Planning Education and Research 358 at 358-366; and JE Innes "Planning Theory's Emerging Paradigm: Communicative Action and Interactive Practice" (1995) 14 Journal of Planning Education and Research 183 at $183-188$. 
extend beyond the owner's boundaries. Homeowners have no right or basis to attempt to control the developments or other activities which occur outside their boundaries, provided these activities do not constitute a nuisance. They are not entitled to a capital gain, therefore have no foundation to object to activities which might reduce the value of their property. Clearer guidance and education to land owners could be provided for in NPSs.

Policies could draw on current principles in employment law like good faith, absence of predetermination and intention to reach compromise. ${ }^{106}$ It could clarify that Councils, developers and the public are expected to enter communications without predetermined ideas (such as NIMBY-ism) and engage with processes and each other in good faith, with the intention of reaching a mutually desirable outcome within a framework of "bottom lines". It could provide education on the mutual benefits of good faith participation and encourage meaningful front end engagement. It could clarify to the public the purpose of consultation is to facilitate public engagement, not to over-politicise planning and enable public coercion of Councils. Effective front end participation could educate the public on the imperative of density and options and the benefits these will have on their city, to increase buy-in to developments.

If the "gate-keeping" mechanism is established, NPSs should identify relevant circumstances and bases for acceptance of appeals to the Environment Court. Factors could include circumstances surrounding front end participation like whether good faith was adhered to and the extent to which proposed developments further the strategic intent of plans and the RMA.

\section{B Current Action}

The Government has recently acknowledged the imperative of using NPS provisions. ${ }^{107}$ It is currently working on a policy statement on urban development capacity, focusing on responsive planning. The draft NPS on Urban Development Capacity (NPS-UDC) has two overarching principles: ${ }^{108}$

(a) actively enabling growth and development; and

(b) understanding property markets and enabling markets to provide for community needs.

Facilitating responsive panning and enabling growth and development are appropriate principles to base policies. NPS-UDC also has provisions to necessitate integrated approaches between planning,

106 See Employment Relations Act 2000, s 4.

107 The only NPSs released before 2008 was the mandatory Coastal Policy Statement. The remaining three were released from 2008-2014, with work currently ongoing for two more. See Ministry for the Environment RMA legislative tools: National Policy Statements (Wellington, 2015).

108 Ministry for the Environment and Ministry of Business, Innovation and Employment Proposed National Policy Statement on Urban Development Capacity: Consultation Document (Wellington, 2016) at 28-29. 
transport and infrastructure, promoting cohesiveness and enabling growth and access. ${ }^{109}$ However NPS-UDC is heavily influenced by the findings of the two Productivity Commission reports. ${ }^{110}$ Policies are premised on conclusions that land supply is artificially constrained and broad deregulation enables the market to achieve social outcomes. The limitations of these assumptions and their ability to achieve density and options have been identified above. This article recommends Government reconsider the direction of NPS-UDC and ensure their growth and development strategies focus on freeing up land "upwards" through intensification, not "outwards" through sprawl and develop policies to increase options.

Policy four of the proposed NPS-UDC describes the "national significance" of urban development and draws heavily on the language of s 5. This could influence the implementation of pt 2 of the RMA because NPSs are presumed to be tools to give effect to it. ${ }^{111}$ NPS-UDC could colour the language of Part 2 and change the relative weight given to "the contribution urban areas make to the social, economic and cultural wellbeing of people and communities". ${ }^{12}$ This could be seen as "legislating through the back door", giving effect to the previously proposed changes to Part 2 through executive action because there was no support for making the changes legislatively. ${ }^{113}$

\section{National Planning Templates}

NPSs will be supplemented by National Planning templates to provide common, user-friendly planning formats, practices and structures. ${ }^{114}$ Templates alleviate long term costs for Councils in preparing plans by reducing complexity and promoting cohesiveness. It also increases certainty and reduces costs in decision-making with less interpretation variations. ${ }^{115}$ However the proposed templates will be mandatory. ${ }^{116}$ This removes Councils autonomy and may discourage local innovation in practice, frustrating the RMA's "bottom up" approach which considers local Government best placed to make decisions affecting their areas. ${ }^{117}$ Government should strive to

109 At 33

110 At 5.

111 Environmental Defence Society Inc v The New Zealand King Salmon Co Ltd, above n 90, at [85]-[90].

112 Ministry for the Environment and Ministry of Business, Innovation and Employment, above n 108, at 10.

113 Palmer, above n 62, at 4 .

114 Ministry for the Environment Resource Management Summary of Reform Proposals (Wellington, 2013) at 6.

115 At 6.

116 New Zealand Planning Institute "Mandatory National Planning Template" (2014) NZPI <www.planning.org.nz> at 7.

117 Palmer, above n 66. 
achieve standardization without assuming too much control over plans. The RMA's model of local decision-making prescribes the Government's role as "involvement" not "intervention".

\section{ACHIEVING DENSITY AND OPTIONS}

Once town plans sufficiently allow for intensification and options, lawmakers should implement measures to more strongly encourage developments which provide density and options in furtherance of the plan's strategy. Lawmakers should consider the best interventions to achieve the intensified range of housing required. This involves an economic analysis of determining which interventions effectively influence developer's behaviours. Whilst such an analysis in beyond the scope of this article, certain measures will be broadly discussed.

\section{A Incentives and Disincentives}

Instead of mere "encouragement", incentives should give tangible reasons for developers to comply with councils' strategic plans. Density bonuses like those in California "loosen" density regulations (such as the ones described above) if developers plan affordable housing. ${ }^{118}$ This is a persuasive incentive, but given this article recommends the outright removal of the very regulations that density bonuses waive, such bonuses would be largely unworkable.

Another persuasive incentive could be grants for financing infrastructure for developments which show strategic potential in their provision of density and options. These should be provided through central government funds as current financial models of local government are insufficient. Central government could provide grants by assessing a development against its compliance with NPSs, the strategic intent of the relevant plan in consultation with the council and the goals of density and diverse housing options. Even the most neo-liberal commentators concede that the New Zealand Government should play a more active role in financing infrastructure, ${ }^{119}$ as there is an existing question regarding whether our current infrastructure is capable of sustaining intensified developments. ${ }^{120}$ As a major cost for developers, infrastructure grants could provide strong incentives to facilitate intensified and varied developments.

Disincentives are a natural corollary to incentives. It is most desirable for incentives and disincentives to work together to form a range of "carrots and sticks" to best achieve desired outcomes.

118 See California Government Code, ss 65915-65918; and Jon E Goetz and Tom Sakai Maximising Density Through Affordability: A Developer's Guide to the California Density Bonus Laws (Kronick Reference Guide, 2015).

119 See interview with Hugh Pavletich, co-author of International Demographia Housing Survey (Heather Du Plessis-Allan, 29 May 2016) at 5:58-8:10.

120 Wellington City Council employee, above n 26. 


\section{B $\operatorname{Tax}$}

Whilst tax is known to be a strong disincentive, the Productivity Commission did not consider tax a major factor in New Zealand's affordability challenges, against its own hypothesis. ${ }^{121}$ It did acknowledge the role of tax in affecting the attractiveness of land as an investment, but did not make recommendations on this point because the actual effect is difficult to quantify. ${ }^{122}$ Some reports dispute the Productivity Commission's finding that tax is not a significant factor in inflating the price of land. ${ }^{123}$ New Zealand does not comprehensively charge any kind of tax on land. Applying taxes to land is controversial in New Zealand's home ownership culture. Land serves dual purposes: it provides a home, but is also a significant asset which confers financial benefits. Failure to tax land ignores this reality and provides windfalls to land-owners. It might also have perverse and nuanced implications if the value of land is severely inflated on the basis that investing in land as an asset will not attract tax, while other investments do.

\section{Rates}

Increased rates is another option to "tax" the ownership of land. It could confer certain benefits over central government taxes, as the revenues would assist local councils with projects and services that directly benefit the neighbourhoods of the homeowners. The primary issue with rates is that it is far more susceptible to local political pressures than a central government tax. The over-politicization of local government decisions in respect to housing is well documented above. Moreover, unlike current proposals relating to increased asset taxes, rates would not be revenue-neutral and could not be offset by income taxes in the way central government taxes could. ${ }^{124}$ Revenue neutrality may be an important political tool to increase public confidence and acceptance of new tax policies. It is likely a shift in social attitudes is required before local government would have a political mandate to impose higher rates as a form of tax.

121 New Zealand Productivity Commission, above n 19, at 88-101.

122 At 83.

123 The effect of tax breaks for land is that consumers invest in land above other assets because land as an asset does not attract tax. This artificially inflates the attractiveness of land as an asset, and thus land prices. This is not the most efficient use of financial capital and affects investment in other value creating assets (which land, in itself, is not). This has been cited as a cause of the current market failures described above. For a full discussion on the economic implications of poor land taxes, see Dr Gareth Morgan New Zealand Income Tax: Unfair and favours the rich (The Morgan Foundation, June 2016) at 5.

124 See D Clifford The Opportunities Party Tax reform (The Opportunities Party, 2016) as an example of current tax reform policy proposals. 


\section{The Bright-Line Rule}

The 2015 budget implemented a "capital gains" tax of sorts which applies to houses purchased and sold within two years, with certain exceptions. ${ }^{125}$ Non-resident buyers must adhere to strong disclosure requirements like obtaining a New Zealand bank account, IRD number and providing Inland Revenue with the tax identification number of their home country and other identification like passport numbers. ${ }^{126}$

These changes give "bite" to existing capital gains tax laws. Inland Revenue historically struggled to enforce capital gains tax due to difficulties in proving intent, which is removed by the rule. ${ }^{127}$ Whilst two years has been criticised as arbitrary, its appropriateness is supported by data which indicates increases in land speculation of under two years to about 15 per cent in Auckland, and 10 per cent throughout the rest of New Zealand. ${ }^{128}$

\section{E Going Further}

The need to go further in addressing issues with foreign ownership has attracted attention. Substantive discussion on this is beyond the scope of this article as it relates to demand, not supply. Broadly, the bright-line rule monitors and disincentivises foreign investment by targeting speculation in general (non-resident purchasers are inherently speculators) without concerning itself with the speculator's nationality. This coincides with New Zealand's obligations under international trade law and various agreements. ${ }^{129}$ It also accords with the reality that the effect of foreign investment on house prices is widely disputed. ${ }^{130}$

These changes are desirable and welcome, but incremental and potentially misplaced. A capital gains tax taxes the transfer of property, whilst the value of assets is accrued throughout the period of ownership, not upon its transfer. Therefore the ownership of property should be taxed, not the transfer. Given land ownership is a vehicle for increasing wealth, the Government should fundamentally re-

125 Taxation (Bright-Line Test for Residential Land) Act 2015, s CB6A.

126 Todd McClay "Budget 2015: Extra Property Tax Measures" (press release, 17 May 2015).

127 Policy and Strategy Division, Inland Revenue Bright-line Test for Residential Land: A Special Report (Wellington, 2015) at 1.

128 Nick Goodall "A look into the length of time properties are held before selling" (25 May 2015) CoreLogic <www.corelogic.co.nz>.

129 See Most Favoured Nation laws: for example, General Agreement on Tariffs and Trade 199433 UNTS 187 (15 April 1994) at art 1(a); and The Beehive "TPP: In Brief" (October 2015) <www.beehive.govt.nz> at 5.

130 See Land Information New Zealand Property transfers and Tax Residency: 1 April-30 June 2016 (Prepared by LINZ, Wellington, August 2016) at Figure 2; and Property Desk "LINZ Data on Foreign Property Buyers a Shambles" (11 May 2016) Property Click <http://propertyclick.nz>. 
evaluate its approach to taxing land as an asset. More comprehensive taxes could also finance potential grants for infrastructure, as discussed above.

\section{F Regulations}

Regulations which ensure intensification and options would be imposed by councils through plans. The Singapore model of inclusionary zoning whereby a range of housing options is required within a development could be implemented. Certain corridors along key transport lines marked for intensified developments could impose minimum density and land-use requirements to ensure the most efficient land-use along these areas. If positive regulations are imposed in specific areas marked for high density (regulations which require specific use instead of prohibiting it), density bonuses could be implemented to incentivise private sector buy-in.

Given the entirely market driven nature of development incentives and the evidence of market failure described above, regulation seems necessary to facilitate a controlled shift in the market away from current trends of large, single lot developments.

\section{SUPPLEMENTARY REFORMS}

The RMA amalgamated 69 Acts to become a "one stop shop" for sustainable resource management. ${ }^{131}$ Government should advance supplementary reforms in other areas to continue promoting a cohesive code of practice amongst all the interconnected elements of resource management and planning, including local government, transport and infrastructure.

\section{A Local Government Act (LGA)}

Reforms to the LGA in 2010 united all the factions of Auckland into one Auckland Unitary Council. ${ }^{132}$ This was instrumental in facilitating a cohesive and consistent town plan which drafted a strategic plan for Auckland as a whole. This increased consistency and efficiency and removed the extensive litigation that historically occurred between the Auckland Councils. Throughout New Zealand, there are many examples of councils which could be amalgamated to achieve the same consistency and cohesiveness. ${ }^{133}$

\section{B Social Housing}

A major contributing factor in New Zealand's history of high property ownership was the mass social housing initiative of the first Labour Government. ${ }^{134}$ Since the 1990s, the Government has divested in state housing and limited eligibility to social housing from the middle class to those

131 Resource Management Act, sch 6.

132 Local Government (Auckland Transitional Provisions) Act, s 3.

133 For example, the Palmerston North City Council is independent from the Manawatu District Council.

134 Ben Schrader We Call It Home: A History of State Housing in New Zealand (Reed, 2005) at 3. 
eligible through the welfare system. ${ }^{135}$ The trend of limiting state's role in housing has continued since. New Zealand's historical experiences and overseas jurisdictions indicate the merits in a stronger government stake in housing markets in facilitating affordability and stability.

\section{Singapore}

A strong example of this is Singapore. After WWII, Singapore suffered major housing shortages and was described by the 1947 British Colonial Government Housing Committee Report as having "one of the world's worst slums". ${ }^{136}$ In 1960, the Housing and Development Act was passed, establishing the Housing Development Board (HDB). ${ }^{137}$ The HDB implemented "the Master Plan" and began mass construction of social housing. ${ }^{138}$ It is now estimated around 88 per cent of Singaporeans live in HDB housing. Singapore is cited as having the highest "home ownership" of any nation in the Demographia survey. ${ }^{139}$

The limitations of the Singapore model should be noted. Commentary describes Singaporeans as having 88 per cent "home ownership". ${ }^{140}$ Houses are bought and sold in the market as if the vendor is transferring a freehold estate. However, HDB houses are leased for 99 years. The Minister for National Development confirmed in 2014 the value of HDB housing at the end of the 99 years is zero as the freehold estate belongs to the government. ${ }^{141}$ The Minister has not provided information on the Government's plan to deal with the situation at the leases' end. This could create major uncertainty and instability in future markets as people attempt to sell their lease towards the end of the 99 years.

Given the uncertainty of 99 year leases, an exact copy of the Singaporean model is not proposed. However the current state of Singapore's housing is a clear example of how mass social housing initiatives facilitate stable and affordable housing markets. New Zealand Government might consider increasing their stake and role in the housing sector, rather than divesting it.

Government stake could facilitate competition by introducing "intensified, affordable housing" into the market, shaping the application of market forces towards density, options and affordability and pushing the market away from its current failures. It could also mitigate the current effects of

135 At 3.

136 Belinda Yuen "Squatters No More: Singapore Social Housing" Global Urban Development Magazine (online ed, November 2007).

137 Housing and Development Act 1960 (Singapore), s 3.

138 See "Master Plan: Written Statement" (1958) Colony of Singapore <www.ura.gov.sg>

139 Day, above n 1 , at 20.

140 See Yuen, above n 136; and Day, above n 1.

141 Gerald Gim "Value of HDB Flats at End of 99-year Lease" (7 February 2014) <http://geraldgiam.sg>. 
market failures on many families in the short term, as Government is in a position to achieve social outcomes like providing low income, rental and starter housing of sufficient quality.

The financial viability of transformative plans has already been outlined. ${ }^{142}$ Further, Government needs to seriously consider its role in aiding affordability in light of the opportunity cost of all the money currently locked in property. If the Government can aid in affordable housing, New Zealanders can reduce debt and spend their money on other goods which circulate money, facilitating a robust economy.

\section{Empirical Research}

One of the primary limitations of this article is its reliance on Government and Council documents and anecdotal evidence because of the lack of empirical research into the RMA's efficacy. The Act's framework is entirely novel, therefore empirical research is necessary to measure its effectiveness and limitations. The Government has blamed affordability challenges on problems regarding zoning and resource management laws. ${ }^{143}$ Claiming the RMA is the substantive barrier to development is difficult to make without empirical research to support it.

\section{CONCLUSION}

This article considers that the way district plans are drafted and implemented needs to be fundamentally re-evaluated and overhauled to achieve intensification and a variety of housing options. This will not be achieved with deregulation which facilitates unlocking greenfill land and exacerbates current market failures. Exclusionary zoning laws which constrain intensification could be removed and replaced with outcomes based approaches: for example assessing development in light of quality building assessment under QIMBY principles. It considers the outcomes focused RMA framework valuable and capable of facilitating density, variety in housing options and affordability whilst balancing environmental bottom lines without substantive reform. Instead, the existing model can be implemented more effectively by changes which give effect to its intention of being a principle-based framework focused on qualitative measures and outcomes. Additionally, NPSs should be released which provide mechanisms on achieving cohesive and strategic plans and rewrites the approach to public participation. This article also supports the implementation of a range of incentives, disincentives and regulations to shift the direction of the market away from its current failures and towards density, options and affordability and supplementary measures to promote cohesiveness between all factions of good planning.

142 World Habitat Awards, above n 54.

143 See Nick Smith, Minister for Housing and the Environment "Overhauling the Resource Management Act" (20th Annual Speech to Nelson Rotary, 21 January 2015). 
